\title{
SCALE EFFICIENCY AND DETERMINANTS OF PRODUCTIVITY OF NEW RICE FOR AFRICA (NERICA) FARMERS IN KADUNA STATE, NIGERIA \\ ${ }^{*}$ Nosiru, O.M.O., M.A.Y. Rahji, A.E. Ikpi and K.O. Adenegan \\ Department of Agricultural Economics, University of Ibadan, Nigeria
}

\begin{abstract}
Rice productivity is low in Nigeria, and NERICA was introduced by West Africa Rice Development Agency (WARDA) to solve this problem. This study focused on NERICA productivity and efficiency in Kaduna State. A three-stage sampling technique was used with Kaduna State being purposively selected. Igabi and Soba Local Government Areas (LGAs) were randomly selected. Five villages were randomly selected from each LGA, with a total of 129 NERICA farmers selected and used for the analysis. There were technical and managerial inefficiencies among the farmers. NERICA production is characterized by increasing returns to scale with a value of 1.4954. The farmers were cost inefficient, hence there was room for improvement in NERICA production in the study area. The average productivity (AP) was 26.30. The average marginal productivity (MP) is 9.213. The average total factor productivity (TFP) is 12.87. Farmer's age and access to credit had negative influence on both AP and MP. Extension contact and adoption of NERICA technology positively influenced the AP and MP. Farmer's age had negative influence on total factor productivity. Formal education, farming experience, extension contact, farm commercialization and adoption of NERICA technology had positive influence on the total factor productivity of the NERICA farmers. Improvements in the supply of NERICA seed, extension services and level of farm commercialization are recommended.
\end{abstract}

Keywords: Scale efficiency, productivity, NERICA, Kaduna State, Nigeria

\section{INTRODUCTION}

Rice is cultivated in all regions of Nigeria. It ranks sixth after sorghum, millet, cowpea, cassava and yam (CBN, 2003). It accounts for about 12 percent of the total cereals produced in Nigeria (CBN, 2004). Five major production systems have been identified. These are the upland rainfed, inland shallow swamp, deep water floating, lowland and irrigated rice production systems (Olayemi, 1997). In 1990, rice yield in Nigeria was 2.07tonnes/hectare. This reduced to as low as 1.3 tonnes/hectare in 2007. In 2012, Nigeria rice yield was 1.88tonnes/hectare (FAO, 2013). The land area under rice cultivation in Nigeria in 2005 was about 2.708 million hectares. But the estimated area planted with rice in 2012 stood at 2.685 million hectares (FAO, 2013). These figures indicated a reduction in area cultivated for rice over the period 2005-2012. Rainfed lowland, upland and irrigated systems accounted for $47 \%, 30 \%$ and $16 \%$ respectively to the total land area devoted to rice production (Daramola, 2005). Among these systems, it is known that 
the rainfed upland system is the least productive (Tiamiyu, 2008). The yield in the rainfed upland is relatively low when compared with the lowland and irrigated production systems (Longtau, 2003). Yet, most rice farmers are in the upland system due to the limited area available for lowland rice production. This is as a result of preference or priority given by government to horticultural crops in the lowland. In 1998, the World Bank gave a \$3 million loan facility to Nigerian Rice Project. In 1999, it gave $\$ 300$ million for horticultural crops under Fadama II project. To improve and encourage the increased production of rice in Nigeria, WARDA bred NERICA for upland ecologies which was introduced to farmers through the Participatory Varietals Selection (PVS) trials in 1999 and 2001. NERICA was to address the problem of low productivity of upland rice in Africa. It promised to be particularly well suited to the low input conditions of rainfed upland rice production system (Dingkuhn et al., 1998; Johnson et al., 1998). It is resistant to drought, weed competition, blast virus diseases, soil iron toxicity and acidity (Jones et al., 1997) and has higher protein content (Diagne, 2006).

The NERICA rice varieties embody improved seed technology to enhance yield and productivity. It embodies management practices in terms of biological and chemical technologies. Production parameters of the adopters of these technologies, their productivity levels and their determinants, the seed's response to inputs and overall, the efficiency of the adopters and how these can be used to solve the problem of low yield, low productivity and rice self-insufficiency in Nigeria require empirical quantification. Hence, this study examined the measures of productivity, scale efficiency, and the factors that influence the productivity measures of NERICA in Kaduna State.

\section{Statement of the Problem}

Nigeria has a problem of demand-supply gap for rice. The local production of rice was estimated to be 3 million tonnes. The current demand then amounts to 5 million tonnes (NAMIS, 2004). Using FAOSTAT (2006) data, rice self-sufficiency ratio over the period 1990 - 2004 was less than one (Rahii and Omotesho, 2006). Oryza News (2012) put local rice production in Nigeria for 2011/2012 season at about 2.7 million tonnes with demand standing at about 5.2 million tonnes. This gives 0.52 rice sufficiency value in 2011/2012 production season.

Central to solving the problem of rice production is therefore the issue of low productivity. The average yield of rice in Nigeria is 1.88 tonnes per hectare which is very low compared to 5.28 tonnes and 9.7 tonnes per hectare in Mauritania and Egypt respectively. There is also the problem of opportunity cost of foreign exchange used in the importation of rice. In 2003, Nigeria imported rice worth over \$US700 million (Bello, 2004). Rice importation was over 5 million tonnes as at 2007, which was equivalent of over \$US 800 million in scarce foreign exchange (Elemele, 2008). The fact that this constitutes a drain on the foreign reserve/exchange of the nation cannot be over-emphasized. The opportunity cost of continued rice importation in Nigeria includes depression of local production such that the introduction of NERICA varieties especially through 
foreign loans/grants might not be the best possible policy option in meeting the self-sufficiency goal of the nation. By putting the money into the Nigerian economy, there will be multiplier effects of increasing local production, providing employment for those already in agriculture and new entrants, and possibly improved processing opportunities for rice in Nigeria, thus reducing the limited capacity of the rice sector to meet domestic demand.

Rice is in high demand in Nigeria. Even with the ban on its importation, it flooded and is still flooding most urban markets in Nigeria. There is thus the need to find an efficient way of increasing its production. The problem in this instance and with respect to NERICA rice is: do we really know the efficiency level of NERICA farmers, whether their operations are efficient or inefficient? What is the productivity level of the farmers? What are the factors determining the measures of productivity of the adopters of NERICA rice?

The problem solving-focus of this study derives from the fact that the NERICA project is an attempt by the government to improve productivity of upland rice production in Nigeria. It is thus important to provide useful information to indicate whether the resources expended on the scheme are justified. More so, the issue of the response of the technology to inputs, the determinants of the productivity of the improved seeds and the scale efficiency of the NERICA upland rice production have not been sufficiently investigated.

\section{Objectives of the Study}

The general objective of this study was to assess productivity and efficiency of NERICA in Kaduna State. The specific objectives were to:

1. examine the scale efficiency of NERICA production in terms of technical, managerial and cost efficiency/inefficiency;

2. determine the measures of productivity for average, marginal and total factor productivity; and

3. identify the socio-economic factors influencing average, marginal and total factor productivity of NERICA farmers in the study area.

\section{METHODOLOGY}

\section{Area of Study}

The area of study was Kaduna State of Nigeria. It is located in the savanna zone of the country. The reason for the choice of the State was its participation in the Participatory Varietal Selection (PVS) trials organized by WARDA in 1999 and 2001. Upland and lowland rice production are the predominant production systems in this area (Tiamiyu et al., 2006).

\section{Method of Data Collection}

Data were collected from upland rice farmers in the state based on their production activities. The primary data were collected with the use of a structured questionnaire. The study used a threestage sampling technique. First, Soba and Igabi LGAs were randomly selected from the pool of 
the prominent LGAs known for NERICA production. Secondly, five villages where NERICA dissemination activities have successfully taken place were randomly selected from each LGA. Thirdly, there was a random selection of 129 NERICA farmers from the study area.

\section{Methods of Data Analysis}

Both the unrestricted and restricted Cobb Douglas production functions are used in this study.

\section{Unrestricted Model}

The specification adopted that of Acheampong and Anoff (2006). The implicit form of the function is given as:

$$
Q_{i}=f\left(X_{1}, X_{2}, X_{3}, X_{4}, X_{5}, u_{i}\right)
$$

This can be specified as a Cobb-Douglas production technology based as:

$$
Q_{i}=A X_{1}{ }^{b 1} X_{2}{ }^{b 2} X_{3}{ }^{b 3} X_{4}{ }^{b 4} X_{5}{ }^{b 5} e^{u i}
$$

The model is log-linearized to obtain the estimating unrestricted equation:

$$
\ln Q_{i}=\ln A+b_{1} \ln X_{1}+b_{2} \ln X_{2}+b_{3} \ln X_{3}+b_{4} \ln X_{4}+b_{5} \ln X_{5}+u
$$

where $Q=$ output in $\mathrm{kg}, X_{1}=$ farm size in hectares, $X_{2}=$ labour in mandays, $X_{3}=$ seeds used in $\mathrm{kg}, X_{4}=$ fertilizer in $\mathrm{kg}, X_{5}=$ herbicides in litres, $u=$ error term, and $b_{i}$ 's are parameters to be estimated. $A=$ managerial efficiency, $\ln A=$ technical efficiency/inefficiency.

In this specification, managerial efficiency in production or the organization of the factors used was measured by $A$. The larger the values of $A$, the more the production activity is managerially efficient, and vice versa. That is, the smaller $A$ is, the less the agricultural activity is managerially efficient. In economic context, $A$ is restricted such that $A>0$ (Acheampong and Anoff, 2006). However, if $A$ is negative, then $A<1$, but if it is positive $A>1$.

\section{The Restricted Cobb-Douglas Model}

This is required to test and confirm the type of returns to scale that characterize the production process. According to Al-Qunaibet et al. (1995), testing the degree of returns to scale can be done by examining the farm technology as described by its production function. To do this requires an imposition of restriction on the Cobb-Douglas production function. The restriction is:

$$
b_{1}=1-b_{2}-b_{3}-b_{4}-b_{5}
$$

This restriction is obtained from the relationship $b_{1}+b_{2}+b_{3}+b_{4}+b_{5}=1$

The substitution of (4) into (3) results in

$\ln Q=\ln A+\left(1-b_{2}-b_{3}-b_{4}-b_{5}\right) \ln X_{3}+b_{1} \ln X_{1}+b_{2} \ln X_{2}+b_{4} \ln X_{4}+b_{5} \ln X_{5}+u_{i}$

The re-arrangement of (5), following Lardaro (1993), produced the estimating restricted estimation as

$\ln \left(\mathrm{Q} / \mathrm{X}_{3}\right)=\ln \mathrm{B}+\mathrm{B}_{2} \ln \left(\mathrm{X}_{1} / \mathrm{X}_{3}\right)+\mathrm{B}_{3} \ln \left(\mathrm{X}_{2} / \mathrm{X}_{3}\right)+\mathrm{B}_{4} \ln \left(\mathrm{X}_{4} / \mathrm{X}_{3}\right)+\mathrm{B}_{5} \ln \left(\mathrm{X}_{5} / \mathrm{X}_{3}\right)+\mathrm{u}$

Where $Q / X_{1}=A P$ (average productivity of seed); In $B=\left[\ln A+\ln X_{1}\right]$ from (5), and Xi's are as already defined. 


\section{Hypotheses}

1. Null hypothesis: The inputs have no significant influence on the response of NERICA output.

$H_{0}: b_{1}=b_{2}=b_{3}=b_{4}=b_{5}=0$

2. Null hypothesis: The production of NERICA is not characterized by increasing/decreasing returns to scale.

$H_{0}: b_{1}+b_{2}+b 3+b_{4}+b_{5}=1$

3. Null hypothesis: The hypothesized factors have no significant influence on the productivity (APP, MPP and TFP) of NERICA.

$H_{0}: a_{1}=a_{2}=a_{3}=a_{4}=\ldots=a_{n}=0$

\section{Hypothesis Testing}

The hypothesis to be tested is that for Constant Returns to Scale. Lardaro (1993) defines the Wald's test (F-test) that can be used to do this as follows:

$$
W . T_{\text {Ш }}=\frac{\left(R S S_{R}-R S S_{U}\right) / r}{\left(R S_{u}\right) / n-K} F_{r, n-K}
$$

This has $F$ distribution with $r$ being the number of restrictions which is one (1) in this case, $n$ is the sample size and $\mathrm{K}$ is the number of parameters in the unrestricted Cobb-Douglas production function.

Decision Rule: (i) if $F$ calculated is less than $F$ tabulated for this test, the null hypothesis is accepted and alternative hypothesis is rejected; (ii) if however, $\mathrm{F}$ calculated is greater than $\mathrm{F}$ tabulated, then the null hypothesis is rejected and alternative hypothesis is accepted.

\section{The Productivity (APP, MPP and TFP) Models}

(i) The total factor productivity model adopted and used in this section borrows from work of Key and McBride (2003). Hence, the total factor productivity is measured as the inverse of the average unit cost of production. It is defined as the inverse of the ratio of total variable cost to total output. The model is approximated by a linear relationship.

$$
\begin{aligned}
& \text { TFP }=\frac{Q}{\text { TVC }} \text { or } \quad \frac{1}{A V C} \\
& =Q / \Sigma^{n} P_{x i} X i \\
& \mathrm{i}=1 \quad \mathrm{n} \text { variable inputs }
\end{aligned}
$$

$\operatorname{TFP}=f\left(z_{1}, z_{2}, z_{3}, \ldots, z_{m}\right)$

Where $m=$ number of variables

TFP $=d_{0}+d_{1} z_{1}+d_{2} z_{2}+d_{3} z_{3}+\ldots+d_{10} z_{10}$

(ii) The average productivity model

$$
\begin{aligned}
& \text { APP }=f\left(z_{1}, z_{2}, z_{3}, \ldots, z_{m}\right) \\
& A P P=d_{0}+d_{1} z_{1}+d_{2} z_{2}+d_{3} z_{3}+\ldots+d_{10} z_{10}
\end{aligned}
$$


(iii) The marginal productivity model

MPP $=f\left(z_{1}, z_{2}, z_{3}, \ldots, z_{m}\right)$

MPP $=d_{0}+d_{1} z_{1}+d_{2} z_{2}+d_{3} z_{3}+\ldots+d_{10} z_{10}$

Where $z_{1}=$ age of farmer (yrs); $z_{2}=$ level of education (yrs); $z_{3}=$ farming experience (yrs); $z_{4}=$ land tenure status (dummy: owning of farmland $=1$, otherwise $=0$ ); $z_{5}=$ household size; $z_{6}=$ credit availability (dummy: farmer benefiting credit $=1$, otherwise $=1$ ); $z_{7}=$ extension contact (number of contact per annum); $z_{8}=$ adoption index (proportion of NERICA technological package utilized on the farm compared to the standard); $z_{9}=$ membership of cooperative (dummy: member $=1$, non-member $=0$ ); $z_{10}=$ commercialization index (proportion of sales compared to the total output); $u=$ error term; $b_{i}^{\prime} s=$ parameters to be estimated.

The APP and MPP are related through the elasticity of production for each variable. The productivity measures are therefore related to one another. The idea behind using the same set of explanatory variables in the productivity models was to identify specific factors that may account for or be useful in explaining the different productivity concepts. 


\section{RESULTS AND DISCUSSION}

\section{Socioeconomic Characteristics of NERICA Farmers}

Table 1: The Socioeconomic Characteristics of the Selected NERICA Farmers

\begin{tabular}{|c|c|c|c|c|c|c|c|}
\hline $\begin{array}{l}\text { Socio-economic } \\
\text { characteristic }\end{array}$ & $\begin{array}{l}\text { Frequ } \\
\text { e-ncy }\end{array}$ & $\begin{array}{l}\text { Percentage } \\
\text { frequency }\end{array}$ & $\begin{array}{l}\text { Mean } \\
\text { (Standard } \\
\text { error) }\end{array}$ & $\begin{array}{l}\text { Socio-economic } \\
\text { characteristics }\end{array}$ & $\begin{array}{l}\text { Freque } \\
n-c y\end{array}$ & $\begin{array}{l}\text { Percentage } \\
\text { frequency }\end{array}$ & $\begin{array}{l}\text { Mean } \\
\text { (Standard } \\
\text { error) }\end{array}$ \\
\hline $\begin{array}{l}\text { Age (years) } \\
20-29 \\
30-39 \\
40-49 \\
50-59 \\
60-69 \\
\text { Total }\end{array}$ & $\begin{array}{l}8 \\
39 \\
43 \\
39 \\
0 \\
129\end{array}$ & $\begin{array}{l}6.2 \\
30.23 \\
33.33 \\
30.23 \\
0 \\
100.00\end{array}$ & $\begin{array}{l}43.46 \\
(0.7339)\end{array}$ & 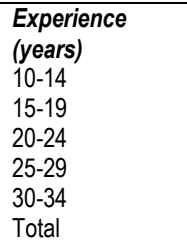 & $\begin{array}{l}1 \\
5 \\
71 \\
44 \\
8 \\
129\end{array}$ & $\begin{array}{l}0.78 \\
3.88 \\
55.04 \\
34.11 \\
6.20 \\
100.00\end{array}$ & $\begin{array}{l}23.74 \\
(0.3213)\end{array}$ \\
\hline $\begin{array}{ll}\text { Level } & \text { of } \\
\text { education } & \\
\text { None } & \\
\text { Primary } & \\
\text { Secondary } & \\
\text { Tertiary } & \\
\text { Total } & \end{array}$ & $\begin{array}{l}78 \\
42 \\
8 \\
1 \\
129\end{array}$ & $\begin{array}{l}60.47 \\
32.56 \\
6.20 \\
0.78 \\
100.0\end{array}$ & $3.75(0.3235)$ & $\begin{array}{l}\text { Land (ha) } \\
<1.0 \\
1.0-1.49 \\
1.5-1.99 \\
2.0-2.49 \\
2.5-2.99 \\
3.0 \text { \&abov } \\
\text { Total } \\
\end{array}$ & $\begin{array}{l}3 \\
99 \\
0 \\
17 \\
9 \\
1 \\
129 \\
\end{array}$ & $\begin{array}{l}2.33 \\
76.74 \\
0.00 \\
13.18 \\
6.98 \\
0.78 \\
100.00 \\
\end{array}$ & $1.44(0.0414)$ \\
\hline $\begin{array}{l}\text { Tenure status } \\
\text { Tenants } \\
\text { Land-owners } \\
\text { Total }\end{array}$ & $\begin{array}{l}26 \\
103 \\
129\end{array}$ & $\begin{array}{l}20.16 \\
79.84 \\
100.00\end{array}$ & & $\begin{array}{ll}\text { Extension } & \\
\text { contact } & \\
\text { None } & \\
\text { Quarterly } \\
\text { Twice } \\
\text { quarter per } \\
\text { Monthly } \\
\text { Total } \\
\end{array}$ & $\begin{array}{l}55 \\
34 \\
\\
33 \\
7 \\
129 \\
\end{array}$ & $\begin{array}{l}42.64 \\
26.36 \\
\\
25.58 \\
5.43 \\
100.00 \\
\end{array}$ & $4.64(0.3155)$ \\
\hline $\begin{array}{l}\text { Level-of } \\
\text { commerciali- } \\
\text { sation } \\
21-30 \\
31-40 \\
41-50 \\
51-60 \\
61-70 \\
71-80 \\
81-90 \\
\text { Total } \\
\end{array}$ & $\begin{array}{l}0 \\
0 \\
16 \\
27 \\
34 \\
26 \\
26 \\
129 \\
\end{array}$ & $\begin{array}{l}0 \\
0 \\
12.40 \\
20.93 \\
26.36 \\
20.16 \\
20.16 \\
100.00 \\
\end{array}$ & $0.67(0.0116)$ & $\begin{array}{l}\begin{array}{l}\text { Level } \\
\text { adoption }\end{array} \\
11-20 \\
21-30 \\
31-40 \\
41-50 \\
51-60 \\
61-70 \\
71-80 \\
81-90 \\
\text { Total }\end{array}$ & $\begin{array}{l}2 \\
29 \\
23 \\
15 \\
9 \\
9 \\
16 \\
26 \\
129 \\
\end{array}$ & $\begin{array}{l}1.55 \\
22.48 \\
17.83 \\
11.63 \\
6.98 \\
6.98 \\
12.40 \\
20.16 \\
100.00 \\
\end{array}$ & $0.53(0.0217)$ \\
\hline $\begin{array}{l}\text { Household size } \\
1-5 \\
6-10 \\
11-15 \\
\text { Total }\end{array}$ & $\begin{array}{l}14 \\
79 \\
36 \\
129\end{array}$ & $\begin{array}{l}10.85 \\
61.24 \\
27.91 \\
100.00\end{array}$ & $9.29(0.2249)$ & $\begin{array}{ll}\text { Credit } & \text { Non- } \\
\text { available } & \\
\text { Available } & \\
\text { Total } & \end{array}$ & $\begin{array}{l}101 \\
28 \\
129\end{array}$ & $\begin{array}{l}78.29 \\
21.71 \\
100.00\end{array}$ & \\
\hline $\begin{array}{l}\text { Cooperative } \\
\text { membership } \\
\text { Non-member } \\
\text { Member } \\
\text { Total } \\
\end{array}$ & $\begin{array}{l}74 \\
55 \\
129 \\
\end{array}$ & $\begin{array}{l}57.36 \\
42.64 \\
100.00 \\
\end{array}$ & & & & & \\
\hline
\end{tabular}

NB: standard error in parentheses

Source: Field Survey, 2012 
Table 1 shows that majority of the farmers fell within the age range of 30 and 59 years of age. About one-third of the farmers were 40-49 years of age. This shows that there was a bright future for rice farming in the State. Most of the farmers did not have any formal education $(60.47 \%)$. Almost one-third of the farmers had primary education, while less than $10 \%$ had secondary and tertiary education. This implies that there was a relatively low level of formal education in the study area. Most of the farmers (79.84\%) owned their farm land while about $20.16 \%$ rented the farm land used for cultivating NERICA. With this, it could be implied that long term fixed capitals could be put in place on the rice farms which could enhance improved productivity. Majority of the farmers $(55.04 \%)$ had farming experience of $20-24$ years, while $34.11 \%$ of the farmers had $25-29$ years of farming experience. This shows that the farmers had the wherewithal required for enhancing improved productivity of rice in the study area. About two-third (61.24\%) of the selected farmers had an average household size of 6-10 members. This shows that the sampled farmers could utilize their household members as sources of farm labour. Almost $70 \%$ of the farmers had very few physical contacts with extension agents. More than $42 \%$ had no contact at all with the extension agents in a year. About $26 \%$ had one contact with the extension agents per quarter. Just $5.43 \%$ had contact with extension agents on monthly basis. This implies that relatively low level of agricultural information could be made available to the farmers in the study area. Majority of the farmers $(78.29 \%)$ had no access to credit for production purpose, while only $21.71 \%$ (less than a quarter) of the farmers had access to credit. This shows a difficulty on the part of the farmers in obtaining agricultural loans which is a key factor in improving agricultural productivity.

About $87.6 \%$ of the farmers offered more than half of their NERICA produce for sale. Two-third of them offered more than $60 \%$ of their produce for sale. More than $40 \%$ of the farmers offered more than $70 \%$ of their produce for sale. The average level of commercialization was $67 \%$. This implies that the sampled farmers were involved in rice farming in Kaduna State mainly for sale rather than for consumption. About forty seven percent of the farmers had more than $50 \%$ level of adoption of NERICA technological package. The remaining $53.48 \%$ had less than $50 \%$ level of adoption of NERICA technological package. The average level of adoption was $53 \%$. This implies that there was a moderate level of adoption of NERICA technology in the State. However, there was still need to improve the level of adoption of this technology among the farmers in the study area. Moreover, $57.36 \%$ of the farmers did not belong to any form of cooperative society, while the remaining $42.64 \%$ were identified with one form of cooperative society or the other. It could be implied that cooperative systems did not gain much ground among the farmers in the study area. The average size of farm land was 1.44 hectare. Majority of farmers cultivated NERICA on farm size between 1.0 and 1.49 hectares, these represented $76.74 \%$ of the total number of the selected farmers. Almost $80 \%$ of the farmers operated on farm land less than $1.44 \mathrm{ha}$. The 
implication of this finding was that most of the rice produced in the study area was cultivated by small scale rice farmers.

Table 2: The Results of the Estimated Unrestricted Production Function of the Selected NERICA Farmers

\begin{tabular}{|c|c|c|c|}
\hline Variables & Constant & t-statistics & Standard error \\
\hline $\ln X_{1}$ (Land) & $-0.2320^{\star \star \star}$ & -3.0518 & 0.0760 \\
\hline $\ln X_{2}$ (Labour) & $1.0160^{* \star *}$ & 5.7767 & 0.1759 \\
\hline $\ln X_{3}$ (Seeds) & $0.3503^{* \star *}$ & 5.0618 & 0.0692 \\
\hline $\ln \mathrm{X}_{4}$ (Fertilizer) & $0.2941^{* * *}$ & 13.3598 & 0.0220 \\
\hline $\ln X_{5}$ (Herbicides) & $0.0670^{* * *}$ & 3.0149 & 0.0222 \\
\hline Constant & -0.1809 & -0.3045 & 0.5940 \\
\hline $\mathrm{R}^{2}$ & 0.9832 & & \\
\hline$R^{-2}$ & 0.9825 & & \\
\hline $\mathrm{N}$ & 129 & & \\
\hline $\mathrm{F}$ & 1441.322 & & \\
\hline RSS & 40.9651 & & \\
\hline RTS & 1.4954 & & \\
\hline
\end{tabular}

Table 2 shows the results of the estimated production function for NERICA in the state. Four out of the five inputs used in production were found to be positive and significant. Land, the fifth factor, was however negative and significant. This means that increases in the level of the positive and significant inputs would result in increases in outputs. The sign on the land variable is against a priori expectation. More so land is the most important factor of production in agriculture. The negative sign could be as a result of estimation error. The $R^{2}$ value of 0.9832 indicated a good fit for the model. This means that $98 \%$ of the variation in the output of NERICA is explained by the variables. The F-calculated has 1441.322 . The critical value at $1 \%$ is 2.80 . The critical value at $5 \%$ is 2.10 . The F-calculated is greater than the tabular value. So the alternative hypothesis state that all the factors in the estimated model have significant effect on NERICA output is accepted. In this way the first hypothesis is tested. 
Table 3: The Results of Estimated Restricted Production Function of the Selected NERICA Farmers

\begin{tabular}{|l|l|l|l|}
\hline Variables & Constant & t-statistics & Standard error \\
\hline $\ln \mathrm{X}_{1} / \mathrm{X}_{3}$ & 0.0664 & 0.8702 & 0.0763 \\
\hline $\ln \mathrm{X}_{2} / \mathrm{X}_{3}$ & $0.1898^{* *}$ & 2.1899 & 0.0867 \\
\hline $\ln \mathrm{X}_{4} / \mathrm{X}_{3}$ & $0.3893^{* * *}$ & 17.4901 & 0.0223 \\
\hline $\ln \mathrm{X}_{5} / \mathrm{X}_{3}$ & $0.1026^{* * *}$ & 6.0259 & 0.0259 \\
\hline Constant & 3.6679 & 10.6690 & 0.3438 \\
\hline $\mathrm{R}^{2}$ & 0.8540 & & \\
\hline $\mathrm{R}^{-2}$ & 0.8493 & & \\
\hline $\mathrm{N}$ & 129 & & \\
\hline $\mathrm{F}$ & 181.3654 & & \\
\hline RSS & 5.8857 & & \\
\hline
\end{tabular}

*** - $1 \%$ significance level; ${ }^{* *}-5 \%$ significance level

Source: Data Analysis, 2012

Table 3 presents the results of the estimated restricted equation. The importance of this equation is to aid in carrying out the linear homogeneity test of the study. In this average production function, three of the variables are found to be positive and significant. These was fertilizer used per seed and herbicide applied per seed which were significant at 1\%. Labour used per seed was significant at $5 \%$. The $\mathrm{R}^{2}$ value for the estimated equation at 0.8540 was high and econometrically acceptable.

\section{The Homogeneity Test}

Table 4: The Results of the Homogeneity Test for the Unrestricted Model

\begin{tabular}{|l|l|l|l|l|l|}
\hline Items & RTS & F-stat & F- 1\% & F-5\% & D.F \\
\hline Values & 1.4954 & 102.6643 & 6.85 & 3.92 & 123 \\
\hline
\end{tabular}

Source: Data Analysis, 2012

The homogeneity test results are presented in Table 4. To obtain the results in Table 4, RSS $S_{R}$, RSSu, $r$ and $n-K$ values of the estimated unrestricted and restricted equations were used following Lardaro (1993). This result test whether the RTS value of 1.4954 was equal to, less than or greater than one. The calculated F-statistics of 102.6643 was greater than the critical or tabular F-values. The null hypothesis which states that the unrestricted function is characterized by constant returns to scale is rejected. This means that the sum of the elasticities of the inputs is significantly greater than 1 ; the alternate hypothesis is thus accepted. In other words, the function is characterized by increasing returns to scale. The numerical scale parameter value is 1.4954 . 
Table 5: Scale Efficiency Measures of NERICA Farmers

\begin{tabular}{|l|l|l|}
\hline Scale measures & $\operatorname{Ln}$ A & A \\
\hline Values & -0.1809 & 0.8345 \\
\hline
\end{tabular}

Source: Data Analysis, 2012

Note: if InA is negative, it implies technical inefficiency.

if InA is positive it, implies technical efficiency.

Table 5 shows a value of 0.8345 . It was less than one as expected. The larger the value relative to zero, the larger the managerial efficiency. This implies that the selected farmers are managerially inefficient. The intercept of the estimated unrestricted equation is negative. The negative sign indicate a technical inefficiency. A positive sign indicates technical efficiency. This implies that the farmers in Kaduna State were technically inefficient in the production of NERICA. The parameter for the model in the study area is negative but insignificant.

\section{The Measures of Productivity of the NERICA Farmers}

Table 6: The Measures of Central Tendency of APP, MPP and TFP of NERICA Farmers

\begin{tabular}{|l|l|l|l|}
\hline Measures & $\begin{array}{l}\text { Average physical } \\
\text { productivity (APP) }\end{array}$ & $\begin{array}{l}\text { Marginal physical } \\
\text { productivity (MPP) }\end{array}$ & $\begin{array}{l}\text { Total factor } \\
\text { productivity (TFP) }\end{array}$ \\
\hline Minimum & 16.67 & 5.84 & 7.69 \\
Maximum & 41.00 & 14.36 & 18.47 \\
Mean & 26.30 & 9.213 & 12.87 \\
Median & 25.83 & 9.0494 & 12.50 \\
Mode & 20.00 & 7.01 & 9.82 \\
Standard error & 0.5308 & 0.1860 & 0.2829 \\
Standard deviation & 6.029 & 2.1120 & 3.2136 \\
\hline
\end{tabular}

Source: Field Survey, 2012

Table 6 shows that the least average physical productivity from the NERICA farmers is $16.67 \mathrm{~kg}$ output of NERICA per kilogram of seed input, while the highest APP is $41 \mathrm{~kg}$ per kilogram of seed input. The mean APP is $26.30 \mathrm{~kg}$ per kilogram of seed input. The mean marginal physical productivity was $9.213 \mathrm{~kg}$. This implies that for every $1 \mathrm{~kg}$ of NERICA seed input introduced into the production process, there was a $9.213 \mathrm{~kg}$ additional output. The minimum MPP was $5.84 \mathrm{~kg}$, while the maximum was $14.36 \mathrm{~kg}$. The mean total factor productivity was 12.87 . This implies that there is an average of $12.87 \mathrm{~kg}$ of NERICA output thousand naira of total variable cost. The minimum TFP was 7.69, while the maximum TFP was 18.47 . 
Table 7: The Frequency Distributions of APP, MPP and TFP of NERICA Farmers

\begin{tabular}{|l|l|l|l|l|l|}
\hline \multicolumn{2}{|l|}{$\begin{array}{l}\text { Average physical } \\
\text { productivity (APP) }\end{array}$} & \multicolumn{2}{|l|}{$\begin{array}{l}\text { Marginal physical } \\
\text { productivity (MPP) }\end{array}$} & \multicolumn{2}{l|}{ Total factor productivity (TFP) } \\
\hline $\begin{array}{l}\text { Class } \\
\text { interval }\end{array}$ & Frequency & $\begin{array}{l}\text { Class } \\
\text { interval }\end{array}$ & Frequency & Class interval & Frequency \\
\hline $15-19.99$ & $24(18.60)$ & $5.5-6.49$ & $8(6.20)$ & $7.5-8.49$ & $6(4.65)$ \\
$20-24.99$ & $32(24.81)$ & $6.5-7.49$ & $31(24.03)$ & $8.5-9.49$ & $16(12.40)$ \\
$25-29.99$ & $31(24.03)$ & $7.5-8.49$ & $13(10.08)$ & $9.5-10.49$ & $25(19.38)$ \\
$30-34.99$ & $33(25.58)$ & $8.5-9.49$ & $18(13.95)$ & $10.5-11.49$ & $7(5.43)$ \\
$35-39.99$ & $8(6.20)$ & $9.5-10.49$ & $17(13.18)$ & $11.5-12.49$ & $10(7.75)$ \\
$40-44.99$ & $1(0.78)$ & $10.5-11.49$ & $26(20.16)$ & $12.5-13.49$ & $10(7.75)$ \\
& & $11.5-12.49$ & $7(5.43)$ & $13.5-14.49$ & $3(2.33)$ \\
& & $12.5-13.49$ & $6(4.65)$ & $14.5-15.49$ & $15(11.63)$ \\
& & $13.5-14.49$ & $3(2.33)$ & $15.5-16.49$ & $14(10.85)$ \\
& & & & $16.5-17.49$ & $12(9.30)$ \\
& & & & $17.5-18.49$ & $11(8.53)$ \\
\hline
\end{tabular}

Source: Field Survey, 2012

NB: Percentages in parentheses

Majority of the farmers fell within 20-34.99 APP regimes. More than one quarter of the farmers fell within 30-34.99 APP regimes. More than 40 percent of the farmers produced below the average APP. Almost one quarter of the farmers fell within 6.5-7.49 MPP regime, while about one-fifth fell within 10.5-11.49 MPP regimes. More than40 percent of the farmers produced below the average MPP. About one-fifth of the farmers fell within 9.5-10.49 TFP regimes. About half of the farmers produced below average TFP in the study area.

Table 8: The Determinants of Average Productivity of the Selected NERICA Farmers

\begin{tabular}{|l|l|l|l|}
\hline Variables & Coefficient & Standard error & t statistic \\
\hline Constant & 25.1637 & 4.2525 & $5.9174^{\star \star \star}$ \\
Age & -0.2225 & 0.0655 & $-3.3971^{\star \star *}$ \\
Education & 0.1297 & 0.1232 & 1.0532 \\
Tenure status & 0.2073 & 0.7087 & 0.2924 \\
Experience & 0.0962 & 0.0996 & 0.9656 \\
Household size & 0.2175 & 0.1573 & 1.3829 \\
Extension contact & 0.6860 & 0.1501 & $4.5712^{\star \star *}$ \\
Credit & -2.2409 & 0.9287 & $-2.4130^{\star \star}$ \\
Commercialization & 2.7407 & 4.5481 & 0.6026 \\
Adoption & 6.2072 & 2.8212 & $2.2002^{\star *}$ \\
Cooperative membership & 0.0270 & 0.6445 & 0.0419 \\
& & & \\
\hline $\mathrm{R}^{2}=0.7948$ & $\mathrm{R}-2=0.7774$ & Standard error $=2.8445$ & $\mathrm{~N}=129$ \\
\hline
\end{tabular}

Source: Field Survey, 2012

NB: ${ }^{* *}$ - $1 \%$ significance level; ** - $5 \%$ significance level 
Table 9: The Determinants of Marginal Productivity of the Selected NERICA Farmers

\begin{tabular}{|l|l|l|l|}
\hline Variables & Coefficient & Standard error & $t$ statistic \\
\hline Constant & 8.8148 & 1.4897 & $5.9174^{\star \star *}$ \\
Age & -0.0779 & 0.0229 & $-3.3971^{\star * *}$ \\
Education & 0.0454 & 0.0431 & 1.0532 \\
Tenure status & 0.0726 & 0.2483 & 0.2924 \\
Experience & 0.0337 & 0.0349 & 0.9656 \\
Household size & 0.0762 & 0.0551 & 1.3829 \\
Extension contact & 0.2403 & 0.0526 & $4.5712^{\star \star *}$ \\
Credit & -0.7850 & 0.3253 & $-2.4130^{\star *}$ \\
Commercialization & 0.9601 & 1.5932 & 0.6026 \\
Adoption & 2.1744 & 0.9883 & $2.2002^{\star *}$ \\
Cooperative membership & 0.0095 & 0.2258 & 0.0419 \\
\hline $\mathrm{R}^{2}=0.7948$ & $\mathrm{R}^{-2}=0.7774$ & Standard error $=0.9964$ & $\mathrm{~N}=129$ \\
\hline
\end{tabular}

Source: Field Survey, 2012

$N B:{ }^{* * *}-1 \%$ significance level; ** $-5 \%$ significance level

Tables 8 and 9 present the results of the socio-economic factors that influenced average productivity and that of marginal productivity. The two tables are about the same. The significant variables that determined both productivity measures were the age of the farmer, number of extension contact, credit availability and level of adoption of NERICA technology. The younger farmers in the study area were more productive than the older farmers. This might be plausible because the younger farmers were expected to have more vigour for farm activities than the older ones ceteris paribus. Farmers that had benefit of more extension services were found to be more productive than those with little or none of such services. This was expected because new agricultural and technological innovations that enhanced productivity were disseminated through such extension services. Farmers with no access to credit facilities were more productive than those that had access to credit facilities. This might be as a result of not judiciously using the available credit facilities, or diverting such to non-productive activities. Moreover, farms with higher level of adoption of NERICA technology were more productive than those with lower level of the technological adoption. This shows that the utilization of the rice variety is very essential for improved farmers' productivity. The alternative hypothesis that collectively, the socio-economic characteristics have effect on each of the productivity measures is accepted. In all cases, the F calculated was greater than the tabulated values. In this way, the third hypothesis is tested. 
Table 10: The Determinants of Average Total Factor Productivity of the Selected NERICA Farmers

\begin{tabular}{|l|l|l|l|}
\hline Variables & Coefficient & Standard error & t statistic \\
\hline Constant & 5.6665 & 1.4639 & $3.8708^{* *}$ \\
Age & -0.0606 & 0.0225 & $-2.6903^{* * *}$ \\
Education & 0.0814 & 0.0424 & $1.9198^{*}$ \\
Tenure status & -0.1523 & 0.2440 & -0.6241 \\
Experience & 0.0738 & 0.0343 & $2.1521^{* *}$ \\
Household size & -0.0168 & 0.0541 & -0.3102 \\
Extension contact & 0.0857 & 0.0517 & $1.6588^{*}$ \\
Credit & -0.2123 & 0.3197 & -0.6640 \\
Commercialization & 9.0647 & 1.5657 & $5.7896^{* * *}$ \\
Adoption & 3.7196 & 0.9712 & $3.8299^{* * *}$ \\
Cooperative membership & 0.0214 & 0.2219 & 0.0965 \\
\hline $\mathrm{R}^{2}=0.9144$ & $\mathrm{R}^{-2}=0.9072$ & Standard error $=0.9792$ & $\mathrm{~N}=129$ \\
\hline \multicolumn{3}{|l}{} \\
Source: Field Survey, 2012 \\
NB: ${ }^{* * *}$ - 1\% significance level; ** - 5\% significance level; * - 10\% significance level
\end{tabular}

Table 10 shows the result of the socio-economic factors that influenced total factor productivity. It has slight difference compared to that of average productivity and marginal productivity. The significant variables that determined total factor productivity included the age of the farmer, level of formal education, farming experience, extension contact, level of farm commercialization and level of adoption of NERICA technology. The younger farmers in the study area were more productive than the older farmers. This might be plausible because the younger farmers were expected to have more vigour for farm activities than the older ones ceteris paribus. Level of formal education seemed to contribute to total factor productivity of the farmers. This may be expected as education has a way of helping the farmers in reasonably committing their resources to any productive enterprise. The higher the levels of farming experience of the farmers, the higher their level of total factor productivity. Farmers that had benefit of more extension services were found to be more productive than those with little or none of such services. This is expected because new agricultural and technological innovations that enhanced productivity were disseminated through such extension services. Moreover, level of commercialization of the NERICA farms seemed to contribute to the farmers' total factor productivity. Thus, the highly commercialized farms were more productive than the less commercialized ones. Also, farmers with higher levels of adoption of NERICA technology were more productive than those with lower level of adoption of the technology. This shows that the utilization of the rice variety is very essential for improved farmers' total factor productivity. 


\section{CONCLUSION}

It is evident that through ensuring improved farm efficiency and productivity, Nigeria could reduce its dependence on imported rice. The results revealed that the returns to scale in NERICA production are increasing. Hence, there is need for optimal increase in the level of rice production. The results further revealed that the NERICA farmers in the study areas were not technically, managerially and cost efficient in their production system.

\section{RECOMMENDATIONS}

The following recommendations are desirable for the improvement in the farmers' efficiency and productivity.

1. Farmers operating on small scale rice farms should be encouraged to increase their farm size to medium and large scale farms.

2. Government should institutionalize a program for an accelerated promotion and adoption of NERICA technology particularly in the study area and in other regions in the country where there is comparative advantages in favour of rice, so as to improve the efficiencies of the farmers.

3. The extension delivery agencies should be strengthened for increase in extension services.

4. In most of the programs, focusing on improving rice productivity, attention should be given more to the youths involved in rice farming.

5. Financial institutions should fashion out ways to curb giving out credits to the farmers that would not judiciously utilize such for production purposes.

\section{REFERENCES}

Al-Qunaibet, M., M. Limam, and B. Sofian (1995). Testing for returns to scale in dairy farms in Saudi Arabia. Journal of King Saud University, Agricultural Science. 7:3-11.

Bello, A. (2004). Nigeria imported \$US 700million rice in 2003 - Federal Minister of Agriculture and Rural Development Mallam Adamu Bello in Nigerian Tribune Newspaper, Monday, 7th July, 2004. Backpage.

Central Bank of Nigeria (2004). Annual Report and Statement of Accounts. Abuja, Nigeria: CBN Publication.

Central Bank of Nigeria. (2003). Annual Report and Statement of Accounts. Abuja, Nigeria: CBN Publication.

Daramola, Biyi (2005). Government policies and competitiveness of Nigerian rice economy. Paper presented at the workshop on rice policy and food security in Sub-Saharan Africa organized by Africa Rice Centre (WARDA), Cotonou, Republic of Benin, November 7-9, 2005.

Diagne, A. (2006). Diffusion and adoption of NERICA rice varieties in Cote d'lvoire. The Development Economics, 44 (2):208-231.

Dingkuhn, M., M.P. Jones, D.E. Johnson and A. Sow (1998). Growth and yield potential of Oryza sativa and Oryza glaberrima upland rice cultivars and their interspecific progenies. Field Crop Research 57 (1): 57-69. 
Elemele, F. (2008). Response of upland rice cultivars to weed completion in the Savannas of West Africa. Available at:<http://www.linkinghu.elsevier.com/retrieve/pii/s0201219408001774> [Accessed 11 August 2011]

FAOSTAT (2006). www.fao.org Accessed March 15, 2006.

FAOSTAT (2013). www.faostat.org Accessed August 26, 2013.

Gujarati, N.D. (1995). Basic Econometrics, McGraw-Hill: Singapore.

Gujarati, N.D. (1999). Essentials of Econometrics, Second Edition, McGraw-Hill International Editions.

Johnson, D.E., M. Dingkuhn , M.P. Jones and M.C. Mahamane (1998). The influence of rice plant type on the effect of weed competition on Oryza sativa and Oryza glaberrima. Weed Research, 38(3): 207-216.

Jones , M.P., M. Dingkuhn, D.E. Johnson, and S.O. Fagade (1997). Interspecific hybridization progress and prospect. Proceeding of the workshop of Africa/Asia Joint Research on interspecific hybridization between African and Asian rice species: Oryza sativa and Oryza glaberrima, Bouake, WARDA.

Key, N. and W. McBride (2003). Production contracts and productivity in the US hog sector. American Journal of Agricultural Economics, 85 (1):121-133.

Lardaro, L. (1993). Applied Econometrics, 1st Edition, New York: Harper-Collins.

Longtau, S.R. (2003). Multi-agency partnerships in West Africa Agriculture: Review and description of rice production systems. Report prepared by eco-systems development organization for oversea Development Institute.

NAMIS (2004). N Nigerian Agricultural Marketing News Bulletin No. 4. www.afmin.net Accessed 03/09/2004.

Olayemi, J.K. (1997). The Nigerian rice industry: performance, problems and prospects. A research report pre pared for Food and Agriculture Organization, FAO; December, 1997.

Oryza News (2012). Nigeria's 2015 Rice-Sufficiency Target Achievable, Says Farmers Association Chairman March 29, 2012.

Rahji, M.A.Y. and O.A. Omotesho (2006). Technical inefficiency and competitiveness in production: the case of rice farmers in Niger State, Nigeria. Agrosearch. 8(1):67-79.

Thirlwall, A.P. (1995). The terms of trade, debt and development: with particular reference to Africa. African Development Review, African Development Bank. 7(1)1-34.

Tiamiyu, S.A. (2008). Efficiency and technology use among growers of NERICA rice varieties in the Savanna zone of Nigeria, Unpublished Ph.D Thesis, University of Ibadan.

Tiamiyu, S.A., A.S. Gana and A.A. Gbanguba (2006). Modern technology adoption and distribution of income from rice production in Nigeria. Proceeding of the 1st Africa Rice Congress, Dar-es-Salam, Tanzania, 29 July - 3 August, 2006. 